\title{
First SARS-CoV-2 Infection in Patients with Severe Asthma Receiving Mepolizumab
}

\author{
Mepolizumab Alan Ağır Astım Hastalarında İlk SARS-CoV-2 Enfeksiyonu
}

Emel Atayık, Gökhan Aytekin

\section{Abstract}

Severe acute respiratory syndrome coronavirus (SARSCoV)-2 is a zoonotic viral pathogen belonging to the same family as SARS-CoV. To the best of our knowledge, no case that was receiving mepolizumab for severe asthma and that developed COVID-19 has been reported to date in literature. In September 2020, a 61-year-old male patient undergoing monthly mepolizumab treatment for the last 6 months, in addition to his current asthma treatment, was admitted to our clinic with complaints of high fever (38$38.5^{\circ} \mathrm{C}$ ), loss of senses of taste for $3-4$ days, as well as nonproductive cough and shortness of breath. Patchy ground-glass densities were observed in basal parts of lower lobes of both lungs, and the patient recorded a positive nasopharyngeal real-time PCR SARS-CoV-2 test. The patient was initiated on hydroxychloroquine, favipiravir and an anticoagulant, and home quarantine was recommended. The patient's complaints had relieved significantly by day 5 of the treatment. There is a need for larger and more extensive studies on the effect of medications used for the treatment of patients with severe asthma on COVID-19 infection, and due to its antiviral effects, the potential favorable contribution of mepolizumab to the treatment of COVID-19 infection in this patient group should be monitored.

Key words: Severe asthma, mepolizumab SARS-CoV-2.

\section{Özet}

Şiddetli akut solunum sendromu koronavirüs (SARSCoV) -2, SARS-CoV ailesiyle aynı aileye mensup, zoonotik bir viral patojendir. Bu zamana kadar, literatürde, ağır astım sebebiyle mepolizumab tedavisi alan ve aynı zamanda COVID-19 gelişen bir olgu bildirilmemiştir. Ağır non-atopik astım tedavisi için son 6 aydır, mevcut astım tedavilerinin yanında, mepolizumab tedavisi uygulanan 61 yaşında erkek hasta, Eylül 2020'de kliniğimize yüksek ateş, son 3-4 günde gelişen koku ve tat duyusunda kayıp, kuru öksürük ve nefes darlığı şikayetleri ile başvurdu. Hastanın akciğer tomografisinde her iki akciğer alt lob bazal kısımlarında yama şeklinde buzlu cam dansiteleri izlendi ve hastanın SARS-CoV-2 için PCR sonucu pozitifti. Hastaya hidroksiklorokin, favipiravir ve antikoagülan tedavi başlandı ve hasta evde karantinaya alındı. Takiplerinde, tedavinin 5. gününde hastanın şikayetleri önemli ölçüde rahatladı. Ağır astım hastalarının tedavisinde kullanılan ilaçların COVID-19 enfeksiyonu üzerine etkilerini inceleyen geniş ve kapsamlı çalışmalara ihtiyaç olduğu aşikar olmakla beraber, anti-viral etkinliği sebebiyle, bu hasta grubunda, mepolizumabın COVID-19 enfeksiyonu tedavisine olumlu katkıları göz ardı edilmemeli ve takip edilmelidir.

Anahtar Sözcükler: Ağır astım, mepolizumab SARSCoV-2.
Department of Allergy and Clinical Immunology, Konya City Hospital, Konya, Turkey
Konya Şehir Hastanesi, Erişkin Allerii ve İmmünoloji Kliniği, Konya

Submitted (Başvuru tarihi): 04.01.2021 Accepted (Kabul tarihi): 17.02.2021

Correspondence (iletişim): Emel Atayık, Department of Allergy and Clinical Immunology, Konya City Hospital, Konya, Turkey

e-mail: emelakinci@yahoo.com 
Severe acute respiratory syndrome coronavirus (SARS(oV)-2 is a zoonotic viral pathogen belonging to the same family as SARS-COV, and is the cause of the respiratory coronavirus disease 2019 (COVID-19) that was declared a pandemic by the World Health Organization (1). As there is still no effective medication or vaccination for SARS-CoV-2, the determination of at-risk patient groups and protection of these patient groups is important. Although viral infections are known to be one of the leading triggers of severe asthma exacerbations, and pulmonary complications are known to be responsible for virus-induced mortality and morbidity, knowledge of the risk status of these patients for COVID-19 is limited and controversial (2). It has been reported that pediatric patients with asthma in particular are less vulnerable to coronaviruses during the previous severe acute respiratory syndrome (SARS) epidemics, when these patients experienced less frequent asthma exacerbations. This suggests that asthma, or the treatments used for asthma exacerbations, may provide protection against COVID-19. Mepolizumab, an anti-IL (Interleukin)-5 monoclonal antibody, is a treatment modality that is used for non-atopic patients with severe eosinophilic asthma. To the best of our knowledge, no case receiving mepolizumab for severe asthma has been reported with COVID-19 in Turkey to date. In this report, we report on the first case to be receiving mepolizumab for severe non-atopic asthma and to have recorded a Polymerase Chain Reaction (PCR) (+) SARS-CoV-2 infection, and discuss this case in the light of literature on the subject.

\section{CASE}

A 61 -year-old male patient being followed-up in our clinic for 20 years with diagnoses of severe eosinophilic asthma, pansinusitis, nasal polyposis and NSAID (Nonsteroidal anti-inflammatory drugs) allergy was receiving monthly mepolizumab (100 mg/4 weeks/subcutaneous) treatment for the last 6 months, in addition to his current asthma treatment (salmeterol/fluticasone $50 / 500 \mathrm{mcg}$, inh, $2 \times 1$; montelukast $10 \mathrm{mg}$, po, $1 \times 2$; salbutamol inh, as needed; ipratropium bromide $1 \times 1$, inh). In September 2020, the patient was admitted to our clinic with complaints of high fever $\left(38-38.5^{\circ} \mathrm{C}\right)$, loss of senses of taste and smell and joint pain, which were present for 3-4 days, as well as nonproductive cough and shortness of breath for 1 day. He had no accompanying disease other than hypertension. A physical examination revealed his general condition to be fine; he was conscious, slightly tachypneic, had a respiration rate of 18 breaths per minutes, $\mathrm{O}_{2}$ saturation of $94 \%$ and a temperature of $38.5^{\circ} \mathrm{C}$. A respiratory system examination, revealed bilateral expiratory rhonchi. In his blood work-up, a hemoglobin level of $13.8 \mathrm{~g} / \mathrm{dl}$ was recorded, and acute-phase reactants were elevated (Table 1). A thorax CT (computerized tomography) carried out for suspected COVID-19 revealed patchy ground-glass densities (viral pneumonia) in the basal parts of lower lobes of both lungs (Figure 1). The patient recorded a positive nasopharyngeal real-time PCR SARSCoV-2 test, and was initiated on hydroxychloroquine (200 $\mathrm{mg}$, po $2 \times 1)$, favipiravir (2x1600 mg loading dose, $2 \times 600 \mathrm{mg}$ maintenance dose, for 10 days) and an anticoagulant (Enoxaparin-Low-molecular-weight heparin 4000 IU 2X1, for 8 days), and home quarantine was recommended. Hospitalization was not considered. The patient's complaints had relieved significantly by day 5 of the treatment. After the patient completed the 10-day quarantine, he was re-evaluated in our clinic. His general condition was fine, he had a body temperature of $36.1^{\circ} \mathrm{C}$ a respiration rate of $16 / \mathrm{min}$ and no pathology other than bilateral prolonged expiration was determined on respiratory system examination. The Mepolizumab treatment (100 mg/ 4 weeks/ subcutaneous) of the patient was continued.

\section{DISCUSSION}

SARS-CoV-2 is a zoonotic virus infection that has spread around the entire world, and has led to one of the most widespread pandemics in history (3). Due to the lack of a medication for the treatment of COVID-19 (4) or the development of an effective vaccine for the prevention of SARS-CoV-2, patients with chronic diseases are at greater risk from such diseases $(5,6)$. During the SARS-CoV-2 outbreak, virus-induced pulmonary complications in particular are responsible for mortality and morbidity (6).
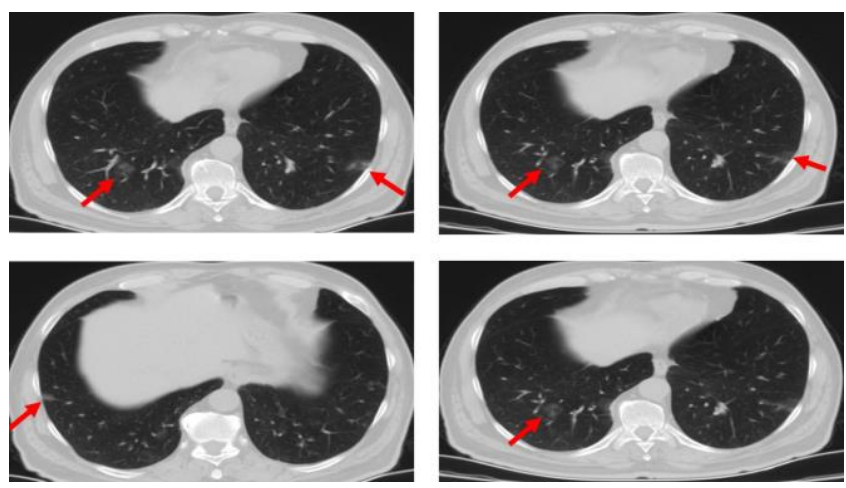

Figure 1: Thorax CT images of the patient 
Table 1: Clinical and laboratory properties of the patient

\begin{tabular}{|c|c|c|c|}
\hline Symptoms & & Laboratory results & \\
\hline Fever & + & White blood cells (109/L) & $7.58(3.91-10.9)$ \\
\hline Chills & + & Lymphocytes (109/L) & $2.07(1,26-3,35)$ \\
\hline Headache & + & Monocyte (109/L) & $0.38(0,29-0,95)$ \\
\hline Bodyache & + & Eosinophils (109/L) & $0(0,03-0,59)$ \\
\hline Fatique & + & Lymphocytes, \% & $27.3(19,1-47,9)$ \\
\hline Vomiting and diarrhea & - & Monocytes, \% & $5.1(5,2-15,2)$ \\
\hline Cough & + & Eosinophils, \% & $0(0,6-7,6)$ \\
\hline Dyspnea & + & $\lg G(g / L)$ & $10.1(7-16)$ \\
\hline Sore throat & + & $\lg M(g / L)$ & $0.7(0.4-2.3)$ \\
\hline \multirow[t]{8}{*}{ Chest pain } & + & $\lg A(g / L)$ & $1.1(0.7-4.0)$ \\
\hline & & $\lg E(I U / m L)$ & $141(0-100)$ \\
\hline & & CRP $(\mathrm{g} / \mathrm{L})$ & $5.5(0-5)$ \\
\hline & & Fibrinogen (g/L) & $478(180-400)$ \\
\hline & & D-Dimer (mg/L) & $0.8(0-2)$ \\
\hline & & Ferritin $(\mu \mathrm{g} / \mathrm{L})$ & $325(18.5-306.5)$ \\
\hline & & Real time COVID-19 PCR & $(+)$ \\
\hline & & White blood cells (109/L) & 7.58 (3.91 - 10.9) \\
\hline
\end{tabular}

As viral infections are among the major causes of asthma exacerbations, and pulmonary complications are mainly responsible for mortality during the SARS-CoV-2 outbreak, the severe asthma patient group was initially considered to be at particular risk from COVID-19 in the initial stages $(2,5,6)$. The results of the first studies on this patient group, however, were in conflict with this prediction, with the proportion of patients with asthma reported to be relatively lower among patients hospitalized for SARSCoV-2 $(7,8)$ in some studies. This was linked to the downregulation of angiotensin-converting enzyme-2 (ACE2) due to the use of inhaled corticosteroids, and corticosteroid-induced prevention of SARS-CoV-2 from entering into respiratory epithelial cells, as well as to the antiviral effects of the immunomodulatory agents used for the treatment of asthma (9-11). This suggests that asthma treatments may be protective against SARS-CoV-2 $(11,12)$. Our case is the first PCR (+) SARS-CoV-2 case to be reported to date, being a patient receiving mepolizumab for severe asthma in Turkey. The lack of cases of SARSCoV-2 being reported in patients with severe asthma receiving mepolizumab since the beginning of the out- break, aside from the current case, and the fact that our patient pulled overcame their COVID-19 infection with relatively mild symptoms support this hypothesis, and suggest that mepolizumab may be protective against COVID-19 infection in the severe asthma patient group.

IL-5 is the most leading interleukin triggering the maturation of eosinophils in bone marrow, their transport to the peripheral bloodstream, and their production, differentiation and activation. Eosinophils internalize the viral antigens in the respiratory tract, exhibiting an antiviral effect; however, internalized viral particles cause a secretion of cytokines and chemokines from eosinophils that trigger respiratory epithelial injury (13). Mepolizumab, an immunomodulatory agent used for the treatment of asthma, is a monoclonal antibody against IL-5 that has been shown to reduce the frequency of asthma exacerbations in patients with severe asthma with an eosinophil count of $150 \mathrm{cell} / \mathrm{ml} 3(14,15)$. Mepolizumab has been shown in many studies to reduce asthma control scores, as well as eosinophilia in the blood or sputum in patients with severe asthma $(14,16)$. Mepolizumab may exhibit a protective effect on the respiratory epithelium by not only pre- 
venting the entry of the SARS-CoV-2 virus into respiratory cells, but also through its eosinophil-reducing effect, and its reduction of the chemokines and cytokines that are secreted by eosinophils in response to SARS-CoV-2 causing epithelial injury. Pineros et al. (17) reported that mepolizumab injections reduce rhinovirus-induced IL-5 secretion by reducing CD62L and CD69 expressions on eosinophils. In the same study, mepolizumab injections were reported to increase the levels of secretory $\lg A$ that exhibits an antiviral effect on the respiratory epithelium of patients with severe asthma. Mepolizumab also exhibits an antiviral effect by increasing the number of natural killer cells - an important part of innate immunity against viruses. Furthermore, mepolizumab has been shown to reduce rhinovirus-mediated $B$-cell and macrophage accumulation in the respiratory epithelium, and to lower the amount of mast cell-induced tryptase in bronchoalveolar lavage $(13,16,17)$. Cumulatively, all these effects suggest that mepolizumab may reduce the epithelial injury caused by a viral infections like SARS-CoV-2, and may provide protection against COVID-19 infection $(4,17)$.

In conclusion, given the lack of an effective treatment or vaccine for the prevention of SARS-CoV-2 infection, the patient group with severe asthma can be considered a potential risk group that requires particular attention. There is an obvious need for larger and more extensive studies on the effect of the medications used for the treatment of patients with severe asthma on COVID-19 infection, and although its effects against COVID-19 and its antiviral effects are hypothetical, the potential favorable contribution of mepolizumab to the treatment of COVID-19 infection in this patient group should be monitored.

\section{CONFLICTS OF INTEREST}

None declared.

\section{AUTHOR CONTRIBUTIONS}

Concept - E.A., G.A.; Planning and Design - E.A., G.A.; Supervision - E.A., G.A.; Funding - G.A., E.A.; Materials - G.A., E.A.; Data Collection and/or Processing - E.A., G.A.; Analysis and/or Interpretation - E.A., G.A.; Literature Review - E.A., G.A.; Writing - E.A., G.A.; Critical Review - E.A., G.A.

\section{YAZAR KATKILARI}

Fikir - E.A., G.A.; Tasarım ve Dizayn - E.A., G.A.; Denetleme - E.A., G.A.; Kaynaklar - G.A., E.A.; Malzemeler G.A., E.A.; Veri Toplama ve/veya İşleme - E.A., G.A.;
Analiz ve/veya Yorum - E.A., G.A.; Literatür Taraması E.A., G.A.; Yazıyı Yazan - E.A., G.A.; Eleştirel İnceleme E.A., G.A.

\section{REFERENCES}

1. Pascarella G, Strumia A, Piliego C, Bruno F, Del Buono R, Costa $F$, et al. COVID-19 diagnosis and management: a comprehensive review. J Intern Med 2020; 288:192-206. [CrossRef]

2. Eger K, Hashimoto S, Braunstahl GJ, Brinke AT, Patberg $\mathrm{KW}$, Beukert A, et al. Poor outcome of SARS-CoV-2 infection in patients with severe asthma on biologic therapy. Respir Med 2020; 177:106287. [CrossRef]

3. Ludwig S, Zarbock A. Coronaviruses and SARS-CoV-2: a brief overview. Anesth Analg 2020; 131:93-6. [CrossRef]

4. Oroojalian F, Haghbin A, Baradaran B, Hemmat N, Shahbazi MA, Baghi HB, et al. Novel insights into the treatment of SARS-CoV-2 infection: An overview of current clinical trials. Int J Biol Macromol 2020; 165(Pt A): 18-43. [CrossRef]

5. Wolff D, Nee S, Hickey NS, Marschollek M. Risk factors for Covid-19 severity and fatality: a structured literature review. Infection 2021; 49:15-28. [CrossRef]

6. Kronbichler A, Effenberger M, Eisenhut M, Lee KH, Shin Jl. Seven recommendations to rescue the patients and reduce the mortality from COVID-19 infection: An immunological point of view. Autoimmun Rev 2020; 19:102570. [CrossRef]

7. Zhang JJ, Dong X, Cao YY, Yuan YD, Yang YB, Yan YQ, et al. Clinical characteristics of 140 patients infected with SARS-CoV-2 in Wuhan, China. Allergy 2020; 75:173041. [CrossRef]

8. Docherty $A B$, Harrison EM, Green CA, Hardwick HE, Pius $R$, Norman L, et al. Features of 20133 UK patients in hospital with covid-19 using the ISARIC WHO Clinical Characterisation Protocol: prospective observational cohort study. BMJ 2020; 369:m 1985. [CrossRef]

9. Bourgonje AR, Abdulle AE, Timens W, Hillebrands JL, Navis GJ, Gordijn SJ, et al. Angiotensin-converting enzyme 2 (ACE2), SARS-CoV-2 and the pathophysiology of coronavirus disease 2019 (COVID-19). J Pathol 2020; 251:228-48. [CrossRef]

10. Cheng $H$, Wang $Y$, Wang GQ. Organ-protective effect of angiotensin-converting enzyme 2 and its effect on the prognosis of COVID-19. J Med Virol 2020; 92:726-30. [CrossRef]

11. Klimek L, Pfaar O, Worm M, Eiwegger T, Hagemann J, Ollert $M$, et al. Use of biologicals in allergic and type-2 inflammatory diseases during the current COVID-19 
pandemic: Position paper of Arzteverband Deutscher Allergologen (AeDA)(A), Deutsche Gesellschaft fur Allergologie und Klinische Immunologie (DGAKI)(B), Gesellschaft fur Padiatrische Allergologie und Umweltmedizin $(\mathrm{GPA})(\mathrm{C})$, Osterreichische Gesellschaft fur Allergologie und Immunologie (OGAI)(D), Luxemburgische Gesellschaft fur Allergologie und Immunologie (LGAI)(E), Osterreichische Gesellschaft fur Pneumologie (OGP)(F) in cooperation with the German, Austrian, and Swiss ARIA groups $(G)$, and the European Academy of Allergy and Clinical Immunology (EAACI)(H). Allergol Select 2020; 4:53-68. [CrossRef]

12. Peters $M C$, Sajuthi $S$, Deford $P$, Christenson $S$, Rios $C L$, Montgomery MT, et al. COVID-19-related genes in sputum cells in asthma. Relationship to demographic features and corticosteroids. Am J Respir Crit Care Med 2020; 202:83-90. [CrossRef]

13. Sabogal Pineros YS, Bal SM, Dijkhuis A, Majoor CJ, Dierdorp BS, Dekker $\mathrm{T}$, et al. Eosinophils capture viruses, a capacity that is defective in asthma. Allergy 2019; 74:1898-909. [CrossRef]

14. Bel EH, Wenzel SE, Thompson PJ, Prazma CM, Keene ON, Yancey SW, et al. Oral glucocorticoid-sparing effect of mepolizumab in eosinophilic asthma. $N$ Engl J Med 2014; 371:1189-97. [CrossRef]

15. Yalcin AD, Yalcin AN. Future perspective: biologic agents in patients with severe COVID-19. Immunopharmacol Immunotoxicol 2021; 43:1-7. [CrossRef]

16. Pavord ID, Korn S, Howarth P, Bleecker ER, Buhl R, Keene $O N$, et al. Mepolizumab for severe eosinophilic asthma (DREAM): a multicentre, double-blind, placebocontrolled trial. Lancet 2012; 380:651-9. [CrossRef]

17. Sabogal Pineros YS, Bal SM, van de Pol MA, Dierdorp BS, Dekker T, Dijkhuis A, et al. Anti-IL-5 in mild asthma alters rhinovirus-induced macrophage, B-cell, and neutrophil responses (MATERIAL). A placebo-controlled, doubleblind study. Am J Respir Crit Care Med 2019; 199:50817. [CrossRef] 